\title{
Scandinavian Approaches to Begging as a Policy Problem and the Double Insider/ Outsider Status of Marginalized Intra-EU Migrants
}

\author{
KARIN BOREVI \\ Södertörn University, Sweden \\ email: karin.borevi@sh.se
}

\begin{abstract}
The present article investigates how begging performed by citizens of new EU-member states in Eastern Europe was debated in parliaments in Denmark, Sweden and Norway during the period 2007-2017. The empirical analysis shows significant cross-country divergences: In Denmark, efforts targeted controlling migration, either directly or indirectly, via various deterrence strategies. In Sweden, the emphasis was rather on alleviating social needs while migrants reside in the country and trying to decrease their incentives to migrate in the first place by ameliorating conditions in sending countries. In Norway, one predominant framing revolved around the issue of human trafficking of beggars. Despite substantial differences, the analyses show a gradual shift in a similar direction in all three countries. While a social frame was initially more commonly understood as the appropriate way to approach begging, over time a criminal frame has gained ground in all three countries. The article argues that this development must be understood in light of marginalized intra-EU migrants' legal status as both insiders and outsiders in the Scandinavian welfare states. Due to these individuals' "in-between status", neither conventional social policy nor immigration control measures are perceived as available, making policymakers more prone to turn to criminal policy tools.
\end{abstract}

Keywords: begging; social policy; migration; free movement; criminal policy

\section{Introduction}

A few years into the new millennium, begging as a policy problem surfaced in political debates across Denmark, Norway and Sweden, as people begging on the streets, outside grocery stores and on public transport became a new and visible trend. After the 2007 accession of Romania and Bulgaria to the EU, there was an influx of migrants from these countries, some of whom made a living through begging, collecting bottles and other forms of informal "street work" (Djuve et al., 2015). The present article suggests that this migrant category status, as both "insiders" and "outsiders", is crucial when analyzing receiving states' approaches to begging that is associated with intra-EU migration. Compared to third-country nationals (TCNs), they are insiders, with the right to free 
movement within the EU/EEA common area. However, in relation to nationals as well as TCNs with a residence right and intra-EU migrants with a job on the formal labor market, they are clearly outsiders, with no access to social rights and no pathways to permanent residence (Tervonen and Enache, 2017; cf. Shutes, 2016). The article explores the "in-between status" of marginalized intra-EU migrants by analyzing how policymakers in Denmark, Sweden and Norway have approached the phenomenon. It is structured in the following manner: Section 2 and 3 present the theoretical argument; Section 4 contextualizes the selected country cases and provides information on data and methods; Sections 5- 7 present the empirical analysis of Denmark, Norway and Sweden; Section 8 offers a concluding discussion.

\section{Framing begging as a social or a criminal policy problem}

According to constructivist approaches to the study of policymaking and theories of framing in policy processes, the way an issue - in our case, begging - is

framed impacts what will be regarded as legitimate and relevant arguments and policy responses (Schön and Rein, 1994; van Hulst and Yanow, 2016). Policy frames serve as cognitive maps, which point actors toward "causal and normative judgments about effective and appropriate policies" within a policy area (Bleich, 2002: 1063).

Based on the literature on how begging has been approached in different countries and during different periods (Erskine and McIntosh, 1999; Hopkins, 2000; Baker, 2009), a distinction can be made between two ideal typical policy frames. According to the criminal frame, begging is understood as being caused by, and/or involving, some form of criminal activity. Consequently, the suggested policy solutions revolve around criminalization and punishment. Following the social frame, begging is instead primarily seen as a symptom of social problems - people turn to begging because of social inequalities, marginalization and discrimination or because they suffer from drug addiction and/or psychological illness. Appropriate policy solutions are therefore formulated in the realm of social and health policies.

Historically, the criminal frame was predominant, as reflected in the introduction in many countries of Vagrancy Acts, etc. Such laws were justified using the notion that "idle beggars" signaled an erosion of work ethics and deservedness norms and/or the perception that beggars were likely participants in further criminality (Baker, 2009). Rulers' concern about the mobility of the poor and control of movement also has ancient roots, although they have now been 'scaled up' from the national to the international level (Andersson, 2013). Several scholars have noted the recurrence of arguments and tropes in presentday policy debates on begging that pertain to the criminal frame (e.g. Erskine and McIntosh, 1999). A variant of the criminal frame (with clear resemblances 
to debates on prostitution as a policy problem) may also be noted when beggars are regarded as crime victims rather than perpetrators, with criminalization and punishment consequently targeting the organizers, traffickers (or pimps), and sometimes the beggars/prostitutes as well. Scholarship on related issues has further pointed out a "punitive turn" in social policies, with increased use of penalization (Wacquant, 2014) and blurred boundaries between "caring" and "coercive" forms of governance (Johnsen and Fitzpatrick, 2010). Notwithstanding this, it seems fair to assume that, in modern welfare states, the social frame generally takes precedence over the criminal frame (Baker, 2009).

The Scandinavian welfare states constitute strong cases for the robust and stable predominance of the social frame, given their generous and comprehensive benefits and welfare services and strong commitment to egalitarian goals and ideology (Kautto, 2010). Indeed, at the time when the begging issue re-entered the scene in relation to intra-EU migrants, the social frame had unquestionably won precedence over the criminal one, as reflected in, e.g. abolishment (Sweden and Norway) of the old begging bans or decriminalization (Denmark) of begging. It therefore stands out as something of a puzzle that the decade that followed (20072017) saw a significant shift in focus and the gradually increasing significance of the criminal frame, in policy debates across all three countries. This is exemplified by parliamentary decisions to re-criminalize begging (in Denmark and Norway) or influential political voices advocating such changes (in Sweden). The argument put forward here is that the increased prominence of the criminal frame can be partly understood as resulting from policymakers' perceptions, based on the legal status of intra-EU migrants, that policy approaches which would otherwise have constituted the appropriate response were unavailable.

\section{Policy approaches to begging and EU migrants' double insider/outsider status}

Whereas immigration generally involves distinguishing "insiders" from "outsiders" (Sales, 2007), intra-EU migrants operating outside the formal labor market are both insiders, under the EU principle of free movement, and outsiders, because economically in-active EU migrants are not eligible for social assistance. The common principle in all three Scandinavian countries analyzed here is that having a legal right to residence is the basis for immigrants' social rights entitlements - although exact conditions, benefit levels, etc, vary both across countries and between immigrant categories (Sainsbury, 2012). Intra-EU migrants operating outside the formal labor market and TCNs with no residence rights (sans papiers) are both categories that can be characterized as "outsiders" in relation to social entitlements. However, the point here is that intra-EU migrants, in their role as EU citizens, enjoy an "insider status" in relation to mobility rights that TCNs do not have. This implies that, for this category, the receiving state 


\section{Begging should be dealt with using...}

\begin{tabular}{|c|c|c|c|}
\hline \multirow{3}{*}{$\begin{array}{l}\text { EU migrants' } \\
\text { in-between } \\
\text { status is... }\end{array}$} & & social policy & immigration control policy \\
\hline & challenged & $\begin{array}{l}1 . \\
\text { EU migrants treated as } \\
\text { insiders: } \\
\text { Access to similar social } \\
\text { policy as natives }\end{array}$ & $\begin{array}{l}2 . \\
\text { EU migrants treated as } \\
\text { outsiders: } \\
\text { Subject to similar immigr. } \\
\text { controls as TCNs }\end{array}$ \\
\hline & $\begin{array}{l}\text { acknow- } \\
\text { ledged }\end{array}$ & $\begin{array}{l}3 . \\
\text { Emergency help } \\
\text { Persuade sending } \\
\text { countries to take their } \\
\text { social policy } \\
\text { responsibilities }\end{array}$ & $\begin{array}{l}4 . \\
\text { Deter EU migrants from } \\
\text { coming/staying } \\
\text { Crimmigration }\end{array}$ \\
\hline
\end{tabular}

FIGURE 1. Potential policy approaches to begging performed by intra-EU migrants

does not have access to immigration control tools (e.g. deportation, return migration or border controls to prevent entry in the first place), which are assumed here to be regarded as the otherwise appropriate responses to begging performed by an "outsider". In sum, intra-EU migrants who perform begging in other member states confound the usual insider/outsider distinctions, which means, in turn, that policy approaches that would otherwise have been perceived as appropriate are regarded as unavailable.

Figure 1 provides a schematic outline of analytically possible ways in which the receiving state may approach this "in-between status", given the aboveexplained premises. One possibility (first row in Figure 1 ) is that the in-between status is challenged. In relation to social policy measures (Position 1), this would imply that intra-EU migrants who are begging in another member state are treated as insiders in the sense that similar social policy measures apply to them as apply to nationals and migrants with social rights entitlements (hence their outsider status is challenged). In relation to immigration control measures (Position 2), the implication is that EU citizens are treated as outsiders and thus subject to similar immigration and border controls as TCNs (hence their insider status is challenged).

If the in-between status of the EU migrants is acknowledged (second row in the figure), what are the possible options? From a social policy perspective (Position 3), the state could offer specially targeted social help and emergency care outside regular social policy programs, and/or encourage NGOs to provide help and provision. Another option, if this position is taken, is to refer to the migrants' home countries' responsibility for taking appropriate social policy measures and making diplomatic efforts to pressure and persuade sending countries to take the necessary social policy measures. From an immigration policy perspective (Position 4), because direct immigration control tools are unavailable, the state could instead try to decrease the so-called pull factors for migration, as an effort at exercising indirect immigration control. This would typically 
involve various kinds of deterrence strategies to discourage "undesired" intraEU migrants from coming and/or staying. It is in relation to this policy option that we would expect policymakers to look for criminal justice measures in response to incidents of begging, resulting in the criminal frame gaining in salience. Indeed, efforts to make it more difficult and less profitable to reside in the country as a homeless foreigner typically involve different punitive and regulative tools, e.g. begging bans, sharpening of penalties for begging and regulations on rough sleeping or illicit camping (Djuve et al., 2015). This strategy comes close to the notion of crimmigration, which is intended to capture the intersection of criminal and immigration law in policies on bordering (Stumpf, 2006) and characterized as "the lumping together of migration and crime in discourse, laws, and practice" (Woude, 2020).

\section{The Scandinavian context}

As already mentioned, the selection of Denmark, Norway and Sweden is justified by their similarities in welfare state ideology and organization, which would cause us to expect predominance of the social frame in relation to issues like begging, homelessness, etc. The Scandinavian countries belong to the same welfare state regime type, often referred to as the Nordic Model or Social Democratic welfare state. This regime type is characterized by its application of comprehensive, generous and redistributive benefits and welfare services, and associated with achievements such as lower income inequality, lower poverty rates and smaller differences in standards of living in an international comparison (Esping-Andersen, 1990; Korpi and Palme, 1998; Kautto, 2010). Immigration policies in all three countries are based on the common premise that strict immigration control is a precondition for welfare state sustainability (Brochmann, 2017), and that social rights based on residence are generally available to immigrants, although variations in models and social stratification exist across the countries (Sainsbury, 2012). Important differences can be noted in relation to incorporation regimes, where particularly Denmark and Sweden appear at opposite poles - with tough assimilatory requirements for new arrivals to gain access to residence and full social entitlements in Denmark and a more "multicultural" and inclusive rights-based approach in Sweden - while Norway takes a position "in between" the two other countries (Borevi et al., 2017; Brochmann and Hagelund, 2012). Differences in the historical representation of populist right-wing parties constitute another contextual factor to be highlighted. Welfare chauvinism as a populist right-wing discourse originates from Denmark and Norway, where so-called Progress Parties already in the 1980 s wanted to restrict welfare rights to 'natives' and exclude migrants (Andersen and Bjørklund, 1990; Larsen, 2020), whereas Sweden only had minor and short-lived right-wing populist parties, until the gradual success of the 
Sweden Democrats, who entered parliament in 2010. Finally, the states differ in the historical development of their relationship to the EU: Denmark joined the EU in 1973 and Sweden in 1995, whereas Norway opted to decline EU membership following referendums in 1972 and 1994 (Ingebritsen, 1998). The right to free movement of persons, however, applies similarly in all the three countries, as Norway is part of the European Economic Area (EEA).

The comparative study presented below is based on systematic searches and analyses of debates pertaining to the issue of begging in Denmark, Norway and Sweden. Parliamentary databases in each country (stortinget.no; ft.dk; riksdagen.se) were searched to identify proposals and opinions expressed on the parliamentary arena during the period 2007-2017 (including government proposals, parliamentary motions, parliamentary reports and debates). The analysis of selected documents has been systematically directed at observing the salience, presence or absence of the frames and potential approaches policymakers may take, following the analytical discussion presented above. All data collection and text analysis were conducted by the author.

\section{Denmark: begging as a problem of immigration control}

In Denmark, the right-wing populist Danish People's Party (DPP) was first in the parliament to draw attention to the issue of foreign beggars, via several questions to the government (2006-2010), calling for sharpened legislation and more forceful usage of the Danish Aliens Act to expel and stop the "traffic of professional beggars", who were said to arrive in Denmark to accost people on the streets. The government responded by downplaying the salience of the problem and emphasizing the insider status of this immigrant category: given the praxis of the European Court of Justice (ECJ), expulsion was only possible if an EU citizen's presence or behavior constituted a serious threat to fundamental societal values, which normally did not apply to persons who were begging. Simultaneously, in a 2009 bill concerning legal changes intended to facilitate expulsion of foreigners, the government took a similar position as the DPP, emphasizing that it was "unacceptable that free movement is utilized by citizens in other EU countries to enter Denmark for shorter stays for the purpose of committing theft and other forms of criminality here in the country", and declaring its intention to sharpen the expulsion praxis for EU citizens committing criminal offences when performing as "gamblers, pickpockets, skill players, beggars or trick thieves" (Government [DK], 2009).

In relation to social policy measures, the prevailing position in the Danish parliamentary material is to limit provisions to homeless foreigners to an absolute minimum, the goal being not to attract more immigration. Voices calling for initiatives to offer social help are in the minority, and they are typically met with the objection that social provisions risk jeopardizing the strategy to decrease pull 
factors. In 2007, the government decided that publicly funded shelters must provide help only to Danish citizens, to avoid Denmark becoming "the shelter of Europe", a policy that was criticized in a 2011 motion by the Red-Green Alliance Party, who instead proposed establishing so-called "transit rooms". These "rooms" would give homeless EU citizens access to basic temporary provisions (shelter, food, basic health care and consultation) so that they would be better prepared when returning to their home countries (Motion [DK], 2011). In the Parliamentary debate, the Conservative Minister of Social Affairs rejected the proposal, saying it would "contribute in attracting foreign citizens who cannot support themselves and who end up as homeless" (Parliament [DK], 2011). He defended the principle that public shelters should normally not provide help to foreign citizens, however adding that exemptions had to be made when there were freezing temperatures. The DPP, in the same debate, held that any social provisions offered to foreigners - even if organized by voluntary actors or provided when it was freezing outdoors - were unacceptable, because they drained resources for homeless Danes and incentivized further immigration (Parliament [DK], 2011).

In 2014, the so-called "three-months rule", according to which an EU citizen may be expelled after having resided in the country for three months, was highlighted in a DPP motion (Motion $[\mathrm{DK}], 2014$ ). Given that it was on the residing state to prove an actual overstay, this rule was difficult to implement, and the motion therefore wanted to reverse the burden of proof, so that EU citizens would be required to document and prove their legal residence in Denmark. The Social Democrats condemned the proposal as being "in contradiction with the entire idea behind the EU", but the Liberal Alliance (LA), the Conservative Party and the Christian Democrats expressed sympathy with the idea, because they agreed that the difficulties associated with expelling EU citizens did indeed constitute a significant problem (Parliament [DK], 2014). In the end, the proposal was rejected because it only received support from DPP and LA. The year after, DPP presented a new proposal, this time to deter immigrants by increasing the penalties for begging (Motion [DK], 2015). The proposal was strongly rejected by the Social Democrats and other parties to the left, not because the sharpened punitive measures targeted at the migrants would be inappropriate as such, but because there was a risk that these measures would also target "our Danish homeless". This is a salient pattern throughout the Danish material: using the criminal frame for foreign beggars and the social one for native Danes. The Social Democratic Minister of Justice explained, e.g. that for foreign beggars the appropriate response was "a more clearly present police force", while the situation was different for Danes: "But in relation to our Danish homeless who are forced to beg since they do not have any means for the day and for the road, I simply do not want to punish them anymore" (Parliament $[\mathrm{DK}], 2015)$. Despite efforts on the part of both DPP and the Conservative Party to ensure that it was foreigners, not homeless Danes, who 
would be affected by sharpened punishments, the Social Democrats were not persuaded, and the motion was rejected.

In 2017 , a new attempt at introducing sharpened punishment was made, this time in a bill from the center-right coalition government, suggesting the removal of regulations that had been in place since the 196os, intended to limit possibilities for the police to enforce the begging ban. For begging committed "on pedestrian streets, at stations, on public transport, and in or around supermarkets", the police should no longer use the praxis of issuing a first warning. Moreover, the penal code was tightened, making it possible to sentence beggars unconditionally to two weeks when first apprehended (Government [DK], 2017). This time, the Social Democrats decided to support the proposal, as they had been given assurances that stricter punishment would only affect foreigners, not Danes. Restrictions would only target so-called "insecuritizing begging", which involved the "intrusive, active" method of begging said to be characteristic of foreigners, whereas Danes' begging style was more passive. In the process (between the different rounds of parliamentary debates), however, it was revealed that the above-mentioned concept lacked legislative value. "Insecuritizing begging" was mentioned in the title of the government bill, but not in the actual legal text. The Social Democrats' decision to maintain their support was met with outrage on the part of the other leftist parties, who suggested that the change in the law was meant to "totally criminalize general begging", stating it was "hypocrisy to say this is a way to protect homeless Danes when the change implies that you will be imprisoned for 14 days if you beg" (Parliament $[\mathrm{DK}], 2017)$. In this context, the option of using conventional immigration control measures to tackle the problem was brought up once again, this time by the Socialist People's Party (SF) and ALT, who held that Denmark should take the lead in making changes in the EU directive to restrict the right of EU citizens to move and reside freely within the union, e.g. by demanding that citizens from other EU countries have a postal address in Denmark to be granted residence. Proponents of re-criminalizing begging, on the other hand, emphasized that this was a constructive solution to a problem where policy tools were very limited, as expressed by one Conservative Party MP: "But when we can see that there is something that actually works, something that the police are happy about, and something that the police can use to solve a problem, that they have not been able to solve before, then it is just a very, very good idea to give them more of the tools that already function. Can you not see that?" (Parliament [DK], 2017).

\section{Norway: begging as a problem of individual exploitation and human trafficking}

In Norway, the begging issue surfaced in national level policy debates as early as in 2005, in relation to a general revision of the Criminal Act involving, among 
many other things, abolishment of the old "Law on Vagrancy, Begging and Drinking", first introduced in 1900 (Government [NO], 2005). The decision was unanimously supported by all parliamentary parties and justified using the argument that criminal punishment was not a normatively defensible response to begging, summarized in the formulation "in a modern society, citizens have to cope with seeing beggars on the street" (Government [NO], 2005) and the declaration, made by the Social Democratic Minister of Justice, that "social policy measures, not criminal policy measures, should be used to avoid people having to resort to begging" (Parliament [NO], 2005). Begging that was "pursued by foreigners", which had recently been seen in the capital and a few other places, was also briefly highlighted in the bill and distinguished from begging performed by Norwegians. Foreigners were said to beg "in a more aggressive and intrusive manner"; they did not seem to suffer from any "visible drug problems"; their begging was perceived as "more professional" and "part of a more organized activity", therefore there was "reason to believe that some are forced to beg" (Government [NO], 2005). Based on the latter suspicion, a law amendment was prepared and passed by the parliament the following year, the goal being to indicate clearly in the criminal law that forcing someone to beg constituted human trafficking (Government [NO], 2006). Thus, begging associated with non-Norwegians was early identified as a problem that required a criminal policy response, which was regarded, however, as compatible with a strong commitment to the social frame, in that "the point of the proposal is that the person who begs will not be punished, but that the punishment will be targeted at the traffickers" (Parliament [NO], 2006). Hence, punishment was appropriate, because it targeted the perpetrators (traffickers) in an effort to help the victims (beggars).

Up until 2013, proposals to introduce regulative measures were rejected with reference to the social frame. In 2007, the Conservatives, Christian Democrats and the right-wing populist Progress Party suggested extending municipalities' capacity to give the police tools to expel beggars who disturbed the public order (Motion [NO], 2007). Three years later, the same parties proposed that municipalities should be allowed to introduce obligatory registration of beggars (Motion [NO], 2010). The majority, however, rejected these proposals on the grounds that they were in contradiction with the 2005 principled stance on the general begging issue, as exemplified by the Social Democratic Minister of Justice's explanation for why the 2007 proposal (referred to above) must be rejected: "De-criminalization has a price. A unified parliament decided to abolish the ban on begging. New Police decrees calling for expulsion of beggars - to the extent they are defined very extensively - may soon be seen to imply that we are indirectly reintroducing the same criminal punishment" (Parliament [NO], 2007).

In 2013, a significant change can be noted. The Progress Party presented a motion to re-introduce a ban on begging, backed by the Conservative Party 
(Motion [NO], 2013). Beggars were still portrayed mainly as victims, but now punishment targeted at beggars was held to be a necessary tool in fighting this exploitation more effectively. As explained by one Conservative Party MP: "... we want to use a tool, as a ban will be, to help some of the people who are being trafficked". Acknowledging this contradicted the stance on approaching begging using social policies, the MP continued: "we do not solve social problems with a ban, but we can perhaps prevent the most grotesque activities that traffickers are dealing with" (Parliament [NO], 2013). Another argument used to justify the ban was that existing tools to track down traffickers were insufficient, because exploitation took place within families as well, as expressed by one Center Party MP: "there are children and youths who do not get an education because their parents want them to join them in begging; also when there are real alternatives, e.g. through EU-financed projects where schooling is part of the offer" (Parliament [NO], 2013). The Progress Party saw the ban mainly as a way to deter criminals from coming to Norway: "as long as it is legal to beg, this is an entry for those coming to commit crimes (it may be in relation to narcotics, human trafficking, burglary, prostitution, etc)" (Parliament [NO], 2013). The three governmental parties (Social Democrats, the Social Liberal Party and the Centre Party) stood united in rejecting the proposal. The Center Party, however, also announced that as a party it was in favor of reintroducing the begging ban (the other statement being a concession to the coalition partners). The parliamentary debate revealed that the Social Democrats had now moved from categorically rejecting any punitive measures (except those targeted at human traffickers), to being open to the possibility of extending regulative tools to allow the police to expel beggars who were "aggressive or intrusive". They still embraced the principled stance that using criminal justice tools was an inappropriate response to begging, but now explained that the dimensions of the begging activities justified some sort of regulative measures (Parliament [NO], 2013).

Later the same year (2013), the Red-Green coalition government proposed sharpened regulative measures against begging. The government was eager to portray this not as a begging ban, but as "a right for municipalities to introduce local regulations concerning when and where people could beg" (Government [NO], 2013). The emphasis was now on understanding beggars as perpetrators of criminal activities and public order offences, rather than as victims. The Social Democratic Minister of Justice expressed unease about using criminal policy tools, but held it was still necessary to take regulatory measures: "Even though this is first of all a social problem, we are clear about the connection between the magnitude of begging and the magnitude of certain forms of criminality, and that there have been public order problems related to, e.g. littering and sanitary conditions". The Liberal Party, Christian Democrats and Social Liberals forcefully opposed the change in law, arguing that "the only humane and liberal solution to the challenge of begging is to handle it as a social problem and solve it 
using social measures", noting also that a ban on begging would not help the stigmatized Roma group move beyond their miserable situation (Parliament [NO], 2013).

After the 2013 elections, the Conservative Party-Progress Party coalition government proposed a municipal ban on begging (Government [NO], 2014), which received a parliamentary majority with the support of the Center Party. A subsequent bill presented two years later - to introduce a national ban on "organized begging" involving, e.g. punishment of persons "facilitating" begging received very harsh criticism and had to be withdrawn, because the Center party no longer wanted to support it. That same year, the Liberal Party made a proposal to abolish the municipal ban on begging introduced in 2013 , but their proposal was rejected by the parliament.

\section{Sweden: begging as a problem of discrimination and social deprivation}

In Sweden, the begging-issue surfaced in parliamentary debates later than in Denmark and Norway. The debates were characterized by strong polarization between the right-wing populist Sweden Democrats (SD) and the other parliamentary parties, where SD most actively tried to politicize the issue in several motions, questions and interpellations, highlighting primarily the negative city image and annoyance beggars allegedly caused by-passers as well as the criminal activities they were said to bring with them. SD's opinions resemble the predominant approach in the Danish policy debates. Framing foreign beggars solely as perpetrators (not victims) of criminality, and as distinguished from homeless Swedes who should be met with social policy measures, SD called for sharpened punitive efforts (including a begging ban) and migration control measures, such as immediate expulsion of non-Swedish citizens who were begging and exemptions to the right to free movement for migrants coming from member states "with a reputation of sending beggars" (Motion [SWE], 2012). Unlike Denmark, in Sweden these proposals were categorically rejected by all other parliamentary parties, including the suggestion to renegotiate the insider status of intra-EU migrants who pursued begging. In the Swedish material, there are instead frequent examples of criticism, and moral indignation, over instances in which the EU treaty is not respected. These instances include the 2010 French expulsions of Roma camps in 2010, which were condemned as "racist and in breach of the EU treaty" (Motion [SWE], 2010), and the expulsion carried out the same year by the Swedish police of 26 homeless nationals from Romania, which received harsh criticism in several motions and interpellation debates. In relation to the latter event, the Swedish police had based their action on a formulation in the Alien's Act, emanating from the old vagrancy act, according to which a foreigner may be expelled "if it can be assumed that he 
or she while staying in Sweden will not support him-/herself in an honest way". The Parliamentary Ombudsmen, JO, in a 2011 report deemed this action to be incorrect and without legal grounds, as begging was not criminalized in Sweden (JO, 2011). The JO verdict was then repeatedly brought up by SD, in motions and interpellations, as a scandalous interpretation of Swedish legislation that enabled "an inflow of beggars and prostitutes who can pursue their activities with reference to EU free movement", while all other parties repeatedly expressed their support for it, maintaining that the 2010 expulsion was wrong (e.g. Parliament [SWE], 2012 A).

Up until 2015, almost all non-SD proposals pertaining to the begging issue revolved around social policy measures. Several proposals and initiatives concerned efforts intended to achieve a change in the situation - particularly for the Roma people - in Romania and Bulgaria, exemplified with the critique expressed by one Social Democratic MP that the (right-of-center alliance) government had not done more to put pressure on Romania and Bulgaria : "I hold that the problem and the solution (...) lie in the fact that many Europeans live in poverty. This cannot be solved only within the borders of Sweden, but we must act to promote changes within the European cooperation. I would have expected the government not to be so passive, but to pursue this issue within the EU" (Parliament [SWE], 2012 B). Calls for initiatives to make long-term improvements in the situation in the home countries were combined with proposals to respond to the short-term needs of marginalized intra-EU migrants residing in Sweden, e.g. efforts to promote and coordinate social help and services provided by Swedish municipalities, state authorities and NGOs.

In the Swedish material, we also find examples of a position that challenges the outsider status of EU migrants in relation to the national social security system. In 2013, the Green Party proposed that homeless EU citizens be offered language education (Swedish for Immigrants, SFI) to increase their possibilities to find a job and that a so-called "shelter guarantee" be introduced for this category of migrants, because "having a shelter is a human right" (Motion [SWE], 2014). The motion also emphasized that the responsibility addressed in the EU Social Security Act must be clarified, which may be taken as another example of a critical stance on approaching intra-EU migrants as outsiders. These proposals were rejected by the parliamentary majority but did not attract the massive critique that much less far-reaching suggestions concerning social provisions for 'foreign beggars' provoked in Denmark, as shown above. Apart from SD, no party in the Swedish parliament problematized social provisions as a possible pull factor for further immigration of poor intra-EU migrants.

In 2015, a shift can be noted, in the sense that other parties began proposing punitive measures to deal with the begging associated with intra-EU migration. The shift was most visible in the Conservative Party. In 2014, the then Conservative Party Minister of Justice had rejected an SD proposal to introduce 
a ban on begging, referring to arguments similar to those used by her Social Democratic predecessor, and all other parties except SD - namely, that "many people who beg are vulnerable and should not be exposed to further stigmatization through being regarded as criminal" (Parliament [SWE], 2014). Only one year later, the Conservative party had made a U-turn and started campaigning for a ban on begging. Their justification was similar to the arguments used in Norway - that beggars were often victims of exploitation and human trafficking, and that a ban was necessary to protect them more effectively. The party wanted to criminalize the "organization of begging", also targeting those who were "facilitating" begging activities, e.g. by "organizing the travel, placing people on different sites and getting paid by others for certain sites are examples which need to be covered by an official inquiry." It also highlighted the need to introduce more effective rules for evicting homeless people who were camping on private property (Parliament [SWE], 2015).

The Social Democrats opposed the idea of a ban, but took some other initiatives involving criminal tools. In June 2015, the Red-Green government launched a reform package aimed at the problem of homeless intra-EU migrants. The package included efforts to cooperate with NGOs, initiatives to have dialogues and cooperation with Romanian and Bulgarian government actors, and funds that were channeled directly to charities and NGOs in Romania and Bulgaria. The reform package also contained three criminal policy proposals: (1) a change in the law that extended the reach of criminal law to offer protection against exploitation (hence, similar to what was introduced in Norway 2006); (2) measures to stop harassment of beggars; and (3) a legal change that made it easier to evict homeless people from unauthorized settlements (Government [SWE], 2015 A). When presenting the reform package, the government also highlighted a crucial pull factor - namely, the almsgiving that allegedly reproduced begging behavior; incentivizing people to come to Sweden and get involved in "degrading begging habits". Moreover, the minister recommended that the public donate money to charities instead of giving it to people on the street (Government [SWE], 2015 B).

\section{Concluding discussion}

Focusing on policy debates in Denmark, Norway and Sweden triggered by the presence of intra-EU migrants begging in public, the present article has analyzed differences between the three Scandinavian countries as well as changes over the period 2007-2017. The results show significant cross-country divergences, particularly regarding how the issue was initially framed when it surfaced in national policy debates. In Denmark, there was a strong impulse to search for solutions within the realm of immigration control policies (challenging free movement within the EU), while the Swedish responses instead focused on 
targeting the "root causes" in the migrants' home countries, while simultaneously coordinating social help for migrants residing in Sweden. In Norway, the main approach to the issue of intra-EU migrants and begging was to use criminal policy tools to track down the traffickers.

Two policy frames summarize the ideal typical responses to begging: according to a social frame, begging is seen primarily as a symptom of social inequalities, marginalization, discrimination or addiction/illness, implying policy solutions in the realm of social and health policies, while a criminal frame instead sees begging as being caused by or involving some form of criminal activity, accordingly suggesting policy solutions that revolve around criminalization and punishment. In relation to migrants, these frames take on potentially new meanings, as illustrated by the analysis of the Danish and Swedish country cases. From a Danish perspective, the emphasis was on trying to decrease pull factors for migration. Punitive measures, targeted at migrants, were thus understood as a desired deterrence strategy, whereas any social provisions offered to intra-EU migrants while residing in the receiving country were rejected as being counterproductive, in the sense that they only encouraged more people to come. In Sweden, emphasis was instead placed on decreasing push factors for migration. Here, punitive and repressive methods were rejected as an inefficient response that only worsened the situation for people suffering from marginalization, discrimination and social misery. The Danish debates are further characterized by the use (by all political actors) of a social frame for Danish beggars and a criminal frame for foreign beggars, while in Sweden such a distinction was only made by the right-wing populist party and rejected by all other parties.

The marked differences between Denmark and Sweden may partly be understood as a spillover effect from the immigration and citizenship regimes that characteristically distinguish the two countries from each other: stricter and more exclusionary in Denmark; softer and more inclusionary in Sweden. The position of the right-wing populist parties is further a crucial factor; in both countries, it was these parties (DPP in Denmark and SD in Sweden) who first put the begging issue on the political agenda and were most active in mobilizing the issue, but the mainstream parties responded very differently. In Denmark, proposals from the DPP already initially attracted support from at least some other parliamentary parties, and gained increasing influence over time, whereas proposals from SD in Sweden were met with massive rejections and condemnations from all other parliamentary parties.

In Norway, the situation differed from the other two countries in several ways. Unlike Denmark, there were no proposals to introduce immigration control, and the focus on solving social problems (either in the migrants' home countries or during their stay in Norway) was less explicit than in Sweden. Instead, the prevailing diagnosis in Norway was that beggars were victims of human trafficking, and the main approach was accordingly to track down 
the perpetrators of this crime. One may argue, however, that this was mainly a discursive framing connected with promotion of a general ban on begging, while relatively few measures were taken to identify and prosecute alleged traffickers (Friberg and Tyldum, 2019). Compared to Denmark and Sweden, the begging issue associated with intra-EU migrants was put on the political agenda remarkably early, in the context of a government-initiated process to abolish the old vagrancy act (i.e. not by a right-wing populist party). The Norwegian debate made strong and explicit commitments to a social frame in policy responses to begging, and the introduction of criminal policy tools targeting traffickers was justified as being compatible with this frame, because beggars themselves were regarded as the victims (not perpetrators) of crime. This framing was common even when the proposed policy tools in fact targeted beggars, such as the failed motion to introduce a national ban on begging.

Despite these differences, all three countries have over time made parallel moves toward a stronger emphasis on the criminal frame. In modern welfare states - particularly the Scandinavian ones - we would expect the social frame to have precedence in relation to issues like begging. Initially this was the case, although interpretations differed somewhat across the three countries. Expressions of a welfare chauvinistic discourse, where the social frame is applied to 'native beggars' and the criminal frame to 'foreign beggars,' are present in all three countries, but Denmark stands out in the sense that this is the predominant approach there, not only the right-wing populist discourse. Nevertheless, in 2017 Denmark sharpened the ban (affecting all beggars irrespective of nationality), thereby reversing the partial de-criminalization that had been introduced in the 1960s. In 2013, Norway introduced a local begging ban, and in Sweden the period post-2015 saw the introduction of punitive efforts in the form of, e.g. evictions, but also party proposals arguing for a begging ban.

The argument pursued in the present article is that the prominence of the criminal frame in relation to begging is a result of the double insider/outsider status of the intra-EU migrants. Due to the "in-between status" of this migrant category, policymakers tend to perceive conventional social policy or immigration control measures as more or less unavailable, instead turning to criminal measures, a process that may be characterized as a form of crimmigration (Stumpf, 2006; Woude, 2020), in the sense that criminal measures are introduced to facilitate border controls. The present analysis supports this argument by documenting how politicians become frustrated when their chosen policy (or non-policy) approach seems insufficient. In Denmark, measures to introduce general re-criminalization of the existing begging ban were taken only after failed attempts to introduce immigration control or to aim criminal tools exclusively at foreigners. The Norwegian abandonment of its previously principled support of the social frame was justified with reference to the magnitude of the problem. The growing salience of a criminal frame in Sweden, although 
not expressed in concrete changes in law, can also be traced to frustration over the failure of previous strategies to solve the problem "here and now". Arguably, this general mechanism - namely, how the unavailability of appropriate policy tools within the realm of immigration or social policy causes policymakers to search for criminal policy tools - has implications for our understanding of policy above and beyond the issue of intra-EU migration for begging.

\section{Acknowledgements}

The author would like to thank the anonymous reviewers for constructive comments and suggestions and to Jon Horgen Friberg, Grete Brochmann, Anne Britt Djuve, Guri Tyldum and Anniken Hagelund for valuable comments on earlier drafts of this text.

\section{Competing Interests}

The author declares none.

\section{References}

Andersen, J. G. and Bjørklund, T. (1990), Structural Changes and New Cleavages: The Progess Parties in Denmark and Norway, Acta Sociologica 33, 3, 195-217.

Andersson, B. (2013), Us and Them? The Dangerous Politics of Immigration Control, Oxford: Oxford University Press.

Baker, D. J. (2009), 'A Critical Evaluation of the Historical and Contemporary Justifications for Criminalising Begging', The Journal of Criminal Law, 73,3, 212-240.

Bleich, E. (2002), 'Integrating Ideas into Policy-Making Analysis: Frames and Race Policies in Britain and France', Comparative Political Studies, 35, 9, 1054-1076.

Borevi, K., Jensen, K.K. and Mouritsen, P. (2017), 'The civic turn of immigrant integration policies in the Scandinavian welfare states', Comparative Migration Studies, 5, 9, 1-14.

Brochmann, G. (2017), 'Immigration policies of the Scandinavian countries', in P. Nedergaard and A. Wivel (eds.), The Routledge Handbook of Scandinavian Politics, London: Routledge, 229-239.

Brochmann, G. and Hagelund, A. (2012), 'Comparison: A Model with Three Exceptions?', in G. Brochmann and A. Hagelund (eds.), Immigration Policy and the Scandinavian Welfare State 1945-2010. Basingstoke: Palgrave Macmillan, 225-275.

Djuve, A. B., Friberg, J. H., Tyldum, G. and Zhang, H. (2015), When poverty meets affluence Migrants from Romania on the streets of the Scandinavian capitals. Oslo: Fafo.

Erskine, A. and McIntosh, I. (1999), 'Why begging offends: Historical perspectives and continuities', in H. Dean (ed.), Begging questions: Street-level economic activity and social policy failure, Bristol: Policy Press, 27-42.

Esping-Andersen, G. (1990), The Three Worlds of Welfare Capitalism. Princeton, NJ: Princeton University Press.

Friberg, J. H. and Tyldum, G. (2019), 'Rumensk tiggermigrasjon i et menneskehandelsperspektiv'. Tidsskrift for Samfunnsforskning, 60,1, 30-49.

Hopkins, B. R. (2000), 'The regulation of begging and vagrancy: A critical discussion', Crime Prevention \& Community Safety, 2,2, 43-52.

Ingebritsen, C. (1998), The Nordic states and European unity. Ithaca, N.Y.: Cornell Univ. Press.

Johnsen, S. and Fitzpatrick, S. (2010), 'Revanchist Sanitisation or Coercive Care? the Use of Enforcement to Combat Begging, Street Drinking and Rough Sleeping in England', Urban Studies, 47, 8, 1703-1723. 
Kautto, M. (2010), The Nordic Countries in F.G. Castles (ed.), The Oxford handbook of the welfare state. Oxford: Oxford University Press.

Korpi, W. and Palme, J. (1998), 'The Paradox of Redistribution and Strategies for Equality: Welfare State Institutions, Inequality and Poverty in the Western Countries', American Sociological Review, 63, 5, 661-87.

Larsen, C. A. (2020), The institutional logic of giving migrants access to social benefits and services, Journal of European Social Policy 30, 1, 48-62.

Sainsbury, D. (2012), Welfare states and immigrant rights: the politics of inclusion and exclusion. Oxford: Oxford University Press.

Sales, R. (2007), Understanding Immigration and Refugee Policies. Contradictions and Continuities. Bristol: Policy Press.

Schön, D. A. and Rein, M. (1994), Frame reflection, New York: Basic Books.

Shutes, I. (2016), 'Work-related Conditionality and the Access to Social Benefits of National Citizens, EU and Non-EU Citizens', Journal of Social Policy, 45, 4, 691-707.

Stumpf, J. (2006), 'The Crimmigration Crisis: Immigrants, Crime, and Sovereign Power', American University Law Review, 56, 2, 368-419.

Tervonen, M. and Enache, A. (2017), 'Coping with everyday bordering: Roma migrants and gatekeepers in Helsinki', Ethnic and Racial Studies, 40, 7, 1114-11131.

Van Hulst, M. and Yanow, D. (2016), 'From Policy "Frames" to "Framing": Theorizing a More Dynamic, Political Approach', American Review of Public Administration, 46, 1, 92-112.

Wacquant, L. (2014), 'The Global Firestorm of Law and Order: On Punishment and Neoliberalism', Thesis Eleven, 122, 1, 72-88.

Woude, M. A. H. van der (2020), Euroskepticism, Nationalism, and the Securitization of Migration in the Netherlands in R. Koulish (ed.), Crimmigrant Nations: Resurgent Nationalism and the Closing of Borders. Fordham University Press.

\section{Primary sources}

Government [DK] (2009), Forslag 2008/09:L174 til lov om ændring af udlændingeloven.

Government [DK] (2017), Forslag 2017/18: L118 til lov om ændring af lov om politiets virksomhed.

Government [NO] (2005), Ot.prp. nr. 113 (2004-2005) Om lov om oppheving av løsgjengerloven og om endringer i straffeloven $\mathrm{mv}$.

Government [NO] (2006), Ot.prp. nr. 50 (2005-2006) Om lov om endringer i straffeloven 1902.

Government [NO] (2013), Forslag til lov. Prop. 152 L (2012-13) endringer i politiloven.

Government [NO] (2014), Prop. 2013/2014:83 L om endringer i politiloven (tigging).

Government [SWE] (2015 A), Att bekämpa utsatthet och tiggeri - ingen ska behöva tigga. https://www.regeringen.se/debattartiklar/2015/o9/regner-skank-till-organisationer-paplats-i-hemlanderna/ [accessed 2020-09-01].

Government [SWE] (2015 B), Skänk till organisationer på plats i hemländerna. https://www. regeringen.se/pressmeddelanden/2015/06/att-bekampa-utsatthet-och-tiggeri/ [accessed 2020-09-01].

JO (2011), Allvarlig kritik mot Polismyndigheten i Stockholms län, som avvisat utlänningar med motiveringen att dessa ägnade sig åt tigger och dagdriveri. Dnr. 6340-2010.

Motion [DK] (2011), Forslag 2010/11: B 106 til folketingsbeslutning om etablering af transitrum for udenlandske hejmløse m.v.

Motion [DK] (2014), Forslag 2013/14: B71 til folketingsbeslutning om EU-borgeres medvirken til documentation af lovligt ophold i Danmark.

Motion [DK] (2015), Forslag 2014/15: B 135 til folketingsbeslutning om ændring af straffelovens bestemmelse om betleri.

Motion [NO] (2007), Representantforslag 8:39 (2006-2007) om å gi hjemmelsgrunnlag til politiet til å gripe inn overfor frembydelse av seksuelle tjenester, organisert tigging mv. 
Motion [NO] (2010), Representantforslag 8:158 S (2009-2010) om bekjempelse av aggressiv tigging via skjerpede politivedtekter.

Motion [NO] (2013), Representantforslag 8:96 S (2012-2013) om handlingsplan mot tigging.

Motion [SWE] (2010), Motion 2010/11: K292. Romer.

Motion [SWE] (2012), Motion 2012/13: Sf258. Förbjud tiggeri.

Motion [SWE] (2014), Motion 2013/14: So241. Hemlöshet.

Motion [SWE] (2015), Motion 2015/16:2304. Åtgärder mot tiggeri.

Parliament [DK] (2011), Behandling af beslutningsforslag 2010/11:B 106 til folketingsbeslutning om etablering af transitrum for udenlandske hjemløse m.v.

Parliament [DK] (2014), Behandling af beslutningsforslag 2013/14: B71 til folketingsbeslutning om EU-borgeres medvirken til documentation af lovligt ophold i Danmark.

Parliament [DK] (2015), Behandling af beslutningsforslag 2014/15: B135 om ændring af straffelovens bestemmelse om betleri.

Parliament [DK] (2017), Behandling af forslag 2017-18: L 118 til lov om ændring af lov om politiets virksomhed.

Parliament [NO] (2005), Behandling av Ot prp. Nr.113 (2004-2005) om lov om oppheving av løsgjengerloven og om endringer i straffeloven mv. 2005-12-15.

Parliament [NO] (2006), Behandling av Ot.prp. nr. 50 (2005-2006) om lov om endringer i straffeloven 1902.

Parliament [NO] (2007), Behandling av representantforslag 8:39 (2006-2007) om å gi hjemmelsgrunnlag til politiet til å gripe inn overfor frembydelse av seksuelle tjenester, organisert tigging $\mathrm{mv}$.

Parliament [NO] (2013), Behandling av representantforslag 8:96 S (2012-2013) om handlingsplan mot tigging och 2012/13:152 L om endringer i politiloven.

Parliament [SWE] (2012 A), Socialförsäkringsutskottets betänkande 2011/12:SfU10. Migration och asylpolitik.

Parliament [SWE] (2012 B), Interpellation 2012/13:509. Tiggeri.

Parliament [SWE] (2015), Interpellation 2014/15:604. Åtgärder för att hindra att utsatta människor utnyttjas i organiserat tiggeri.

Parliament [SWE] (2014), Svar på skriftlig fråga 2013/14:704. Förbud mot hitrest tiggeri. 